\title{
АКТУАЛЬНІСТЬ ПІДГОТОВКИ МЕНЕДЖЕРІВ ДЛЯ ВПРОВАДЖЕННЯ ДЕРЖАВНО-ПРИВАТНОГО ПАРТНЕРСТВА В ОХОРОНІ ЗДОРОВ'Я
}

\author{
Національна медична академія післядипломної освіти імені П.Л. Шупика, м. Київ, Україна
}

Мета: обґрунтувати необхідність підготовки менеджерів для реалізації державно-приватного партнерства у системі охорони здоров'я.

Матеріали і методи. Для досягнення поставленої мети у роботі використано загальнонаукові методи аналізу, синтезу, узагальнення, інтерпретації наукових даних, а також системний і структурно-срункціональний підходи.

Результати. Обґрунтовано доцільність підготовки менеджерів із навичками ефективного економічного управління для закладів охорони здоров'я комунального і регіонального рівнів, які переходять на принципи державноприватного партнерства.

Висновки. Управлінський апарат діючих державних і комунальних закладів охорони здоров'я не в змозі використати економічні важелі та підвищити соціальну та економічну ефективність охорони здоров'я. Пріоритетними напрямками розвитку медичних закладів у нових економічних умовах $€$ фоормування їх господарського механізму на принципах державно-приватного партнерства та підготовка менеджерів для управління новим типом закладів.

КЛЮЧОВІ СЛОВА: державно-приватне партнерство в охороні здоров'я; підготовка менеджерів для державно-приватного партнерства.

В умовах гострого десріциту ресурсів, стагнації промислового виробництва і політичної нестабільності пошук нових інструментів розвитку галузей народного господарства набуває важливого державного значення. У зв'язку з чим, на думку цілого ряду вчених [1-3], найважливішим напрямком розвитку системи охорони здоров'я України у сучасних умовах $€$ активізація державно-приватного партнерства (ДПП).

Поняття державно-приватного партнерства має багато десрініцій, зокрема, ДПП - це: «рорма взаємин між державою або органами місцевого самоврядування та приватними партнерами, які легалізуються у вигляді договору, передбачають реалізацію і спільне фрінансування суспільно значущих проектів на довгостроковій основі та розподіл ризиків, відповідальності та винагород» [4].

Слід відзначити, що в Україні впродовж останніх років зроблені конкретні кроки для підготовки до втілення проектів ДПП в охороні здоров'я. Так, 17 грудня 2015 р. МОЗ України провело нараду 3 міжнародною участю щодо питання впровадження державно-приватного партнерства у сорері охорони здоров'я. Лейтмотивом цієї наради, який відзначили усі доповідачі, була теза, що ефективну систему охорони здоров'я можливо сформувати лише на базі державно-приватного партнерства [5].

ВУкраїні один за одним схвалені закони, які сприяють розвитку державно-приватного партнерства:

- Закон України від 01.07.2010 р. № 2404-VI «Про державно-приватне партнерство» [6].

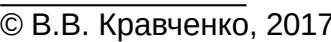

- Закон України від 24.11.2015 р. № 817-VIII «Про внесення змін до деяких законів України щодо усунення регуляторних бар'єрів для розвитку державно-приватного партнерства та стимулювання інвестицій в Україні» [7].

Таким чином, інституційне підґрунтя для реформування галузі охорони здоров'я на принципах державно-приватного партнерства закладено, а ось наскільки воно буде успішним, значною мірою залежить від здатності керівників охорони здоров'я ефективно використовувати нові можливості та здійснювати необхідні перетворення.

Тому підготовка фрахівців із ДПП є особливо актуальною для України, де механізм дПП тільки починає впроваджуватись у практику та не викликає довіри серед представників органів регіональної влади.

Мета дослідження: обґрунтувати необхідність підготовки менеджерів для реалізації державноприватного партнерства у системі охорони здоров'я.

Матеріали і методи. Для досягнення поставленої мети у роботі використано загальнонаукові методи аналізу, синтезу, узагальнення, інтерпретації наукових даних, а також системний і структурнофункціональний підходи. Інсрормаційною базою для виконання дослідження були наукові праці вітчизняних та зарубіжних фрахівців із організації та управління охороною здоров'я.

Результати дослідження та їх обговорення. Проекти ДПП реалізуються у ринковому середовищі, яке має свої економічні закони, створює 
стимули для впровадження інновацій і сприяє есрективному та якісному наданню послуг.

Механізм державно-приватного партнерства передбачає, що держава $€$ замовником послуг. Саме вона визначає умови такого співробітництва, створює умови для прийняття управлінських рішень приватним сектором, а також здійснює постійний моніторинг, при цьому об'єкт інвестування залишається у власності держави.

Для реалізації проектів ДППпотрібні підготовлені керівники, які повинні оволодіти знаннями щодо кращого світового досвіду використання ДПП, варіантів адаптації ДПП для імплементації в умовах України, механізмів державно-приватного партнерства як ефрективного інструменту залучення інвестицій, інновацій та підвищення якості послуг, які надаються населенню.

В умовах державно-приватного партнерства роль організатора, яка була типовою в умовах централізованого управління, змінюється на роль менеджера, управлінця для умов ринкової економіки, за яких складність управлінських завдань різко підвищується. Отримання подібної кваліфікації вимагає, як мінімум, спеціальної підготовки.

Саме різке підвищення складності та комплексності управлінських завдань в умовах ринкової економіки призвело до того, що 3 кінця XIX століття почала фрормуватися спеціальна галузь знань - менеджмент, яка концентрує досвід есрективної управлінської діяльності, а також відповідні теоретичні розробки.

Згідно 3 твердженням класика менеджменту Пітера Друкера, менеджмент - це не управління предметами, а організація і управління працею людей, це система щоденного та перспективного планування, прогнозування та організації виробництва, реалізація послуг із метою отримання максимального прибутку (матеріального, інтелектуального та духовного) [8].

«Рідко, якщо взагалі коли-небудь, який-небудь новостворений інститут так швидко доводив свою необхідність, як розвивався менеджмент з початку нинішнього століття» [9].

Менеджмент в охороні здоров'я - це діяльність, спрямована на підвищення ефрективності закладів охорони здоров'я (303) за допомогою сукупності принципів, методів і засобів, які активізують трудову діяльність, інтелект і мотиви поведінки як окремих медичних працівників, так і всього колективу [10].

Згідно з твердженням М. Портера (2007), для ідеології менеджменту характерні два взаємозалежні стратегічні напрямки.

Перший напрямок полягає у фрормуванні та використанні в управлінні пріоритетних економічних відносин, поступовий перехід від інтуїтивних, дослідно-прагматичних методів управління до дійсно науково обґрунтованих методів і фрорм класичного менеджменту.
Другий напрямок полягає у підвищенні інтелектуальної складової керівників медичних закладів та фрормування якісно нового кадрового ресурсу менеджерів.

У руслі реалізації першого напрямку, керівники закладів охорони здоров'я регіонального та комунального рівнів повинні мати вектор реалізації мети, тобто опис необхідного обсягу теоретичної та практичної підготовки і вміти вирішувати такі завдання:

- аналізувати роботу 303 та умов їх діяльності, у тому числі здійснювати аналіз демографрічної та соціальної сегментації ринку медичних послуг, аналіз статистичних форм звітності, методів цільової диспансеризації щодо виявлення захворювань;

- своєчасно орієнтуватися у зміні структури господарського механізму управління 303 із урахуванням ринкової економіки;

- визначати оптимальну стратегію і тактику ціноутворення у закладах охорони здоров'я, які працюють на принципах державно-приватного партнерства, з урахуванням ринкових умов;

- застосовувати системно-ситуаційний метод i процесний підхід в управлінні діяльністю 303;

- проводити аналіз штатного розпису, принципів оплати праці, підготовки та підвищення кваліфрікації медичного персоналу;

- фрормувати стабільний потік пацієнтів і проводити моніторинг виробничих процесів.

Менеджмент як сучасна концепція управління, як процес ефективного планування, організації виробництва і моніторування виконання виробничих завдань, вимагає від менеджера, який працює у ринкових умовах, чіткого визначення:

- обсягів ринку послуг, які будуть продаватися і купуватися;

- заходів для взаємодії з ринковими структурами;

- конкретних обсягів лікувально-профілактичної допомоги, спрямованої на охорону здоров'я прикріпленого населення, які здатні забезпечити 303;

- заходів відповідальності за досягнення конкретних запланованих результатів діяльності та за ефрективне використання ресурсів [11].

Менеджер в охороні здоров'я також повинен володіти науково обґрунтованими методами і фрормами класичного менеджменту, цільовим і ситуаційним підходами.

Цільовий підхід є основою стратегічного управління і планування, передбачає вибір, обґрунтування та реалізацію чітких та конкретних довго- або короткострокових цілей, які виступають як орієнтири для керівництва 303.

Ситуаційний підхід забезпечує внутрішню побудову системи управління, є відповіддю на дії зовнішнього середовища. В умовах ситуаційного підходу форми, методи, системи, стиль керівництва повинні істотно варіювати залежно від об'єктивних умов організаційного контексту. 
Велика відповідальність лягає на менеджера по роботі з кадрами.

Робота 3 кадровим ресурсом має бути спрямованою на приведення можливостей медичних працівників у відповідність до цілей діяльності медичного закладу, на забезпечення активного зростання, лідерства закладу на ринку і стабільний його розвиток шляхом впровадження інновацій.

Вона має також бути спрямована на:

- оптимізацію процесу взаємодії персоналу 3 пацієнтами, тому що пацієнти є основними інвесторами розвитку медичного закладу;

- планування чисельності персоналу з урахуванням якісної складової (освіта, мотивація, професійні навички персоналу, цінності та ін.);

- добір персоналу на основі чітких критеріїв і розробленої технології відбору, координацію добору з керівниками структурних підрозділів;

- залучення висококваліфікованого персоналу, забезпечення його мотивації та закріплення у 303;

- адаптацію персоналу на основі розробленої технології і контроль за процесом його адаптації та аналіз її ефективності;

- оцінку персоналу на внутрішньому рівні та розгляд атестації виключно як інструменту для отримання кваліфрікаційної категорії;

- стимулювання персоналу на основі розробленої ефрективної системи мотивації;

- фрормування кадрового резерву.

Робота 3 персоналом повинна відповідати вимогам законодавства і сучасним принципам системи менеджменту якості, а також потребам клієнтів, потребам і очікуванням медичного персоналу.

Глобальна мета управління персоналом полягає у фрормуванні ефективного кадрового потенціалу шляхом поліпшення роботи кожного співробітника, нарощування та раціонального використання його трудового і творчого потенціалу. Кадрова політика повинна бути орієнтованою на розвиток цілісної корпоративної культури і конкурентної переваги.

У роботі з кадрами важливими є і такі моменти:

- розвиток лінійного менеджменту - зростання ролі завідувачів відділень (лінійних менеджерів) у кадровій роботі з медичним персоналом та їх інтеграція у стратегію роботи з медичним персоналом закладу в цілому;

- зв'язок кадрового та виробничого планування - кадрове планування має бути повністю інтегрованим у планування діяльності медичного закладу, тобто кадрова стратегія є однією з частин стратегічного плану розвитку закладу;

- ставлення керівництва до медичного персоналу як до об'єкта корпоративної стратегії, фрактора конкурентної переваги, об'єкта інвестицій.

Якісне підвищення інтелектуальної складової керівників медичних закладів та фрормування якісно нового кадрового ресурсу менеджерів $€$ не менш важливим.
В Україні з прийняттям у 2010 р. базового закону «Про державно-приватне партнерство» активізувалися процеси створення інституційного середовища, популяризації та розвитку державноприватного партнерства. Активними учасниками даного процесу стали проекти міжнародних організацій, переважно фрінансовані Агентством США $з$ міжнародного розвитку (USAID), серед них: «Локальні інвестиції та національна конкурентоспроможність», у рамках якого було проведено ряд круглих столів за тематикою ДПП, і видано у 2011 р. практичний посібник для органів місцевої влади та бізнесу «Підготовка та реалізація проектів публічно-приватного партнерства».

«Програма розвитку державно-приватного партнерства» (Public-Private Partnerships Development Program) (жовтень 2010 р. - вересень 2015 р.), у ході реалізації якої були проведені навчальнометодичні семінари для викладачів вищої школи за тематикою «Викладання ключових аспектів державно-приватного партнерства: український досвід».

Програма «Лідерство в економічному управлінні» (Leadershipin Economic Governance) (грудень 2014 р. - грудень 2019 р.), діяльність якої спрямована на підтримку реформ щодо сприяння малому та середньому бізнесу, налагодження сталого державно-приватного діалога, використання інструментів зміцнення потенціалу та інституційної спроможності організацій-учасників, зокрема тих, які здатні підтримати конструктивний діалог із владою щодо вибору напрямків політики для забезпечення конкурентоспроможності приватного сектора.

Також на сьогодні в Україні активно здійснюється профресійне навчання у галузі ДПП: Державне підприємство «Центр розвитку державно-приватного партнерства» (м. Київ); Український центр сприяння розвитку публічно-приватного партнерства (м. Київ) проводять курси підвищення кваліфрікації, тренінги та конфреренції з питань ДПП.

що стосується підвищення квалісрікації керівників у системі охорони здоров'я за тематикою ДПП, то тут стан справ погіршився. А така підготовка керівників $є$ надзвичайно необхідною. Існуюча система післядипломної підготовки лікарів передбачає навчання керівників 303 на циклах спеціалізації за спеціальністю «Організація і управління охороною здоров'я». Але короткотривалість такого навчання (2 місяці) не забезпечує фрундаментальності підготовки, особливо щодо використання принципів ДПП в охороні здоров'я.

Необхідною $€$ сучасна програма підготовки менеджерів охорони здоров'я та перепідготовки управлінського кадрового потенціалу. Така програма повинна навчити менеджерів охорони здоров'я вирішувати завдання організації медичного закладу на базі ДПП, вміло розпоряджатися фрінансовими ресурсами, забезпечувати залучення 
приватних інвестицій для інновацій, формувати есрективний кадровий потенціал.

Однією із складових сучасної підготовки менеджерів охорони здоров'я має стати соціальноетичний маркетинг. Продаж послуг для окремих соціальних груп населення (пенсіонерів, ветеранів війни і праці, одиноких, малозабезпечених, багатодітних, осіб із соціально значущими захворюваннями та ін.). Повинні мати місце елементи зниження цін, етичної спрямованості. Позитивний імідж медичного закладу, його щира благодійність створюють психологічну довіру i, в кінцевому рахунку, забезпечують медичний і економічний ефект.

Вирішення завдання підготовки сучасних менеджерів вимагає компетентного професорсько-викладацького складу, сорормованого 3 представників вищої школи менеджменту, які мають досвід роботи з програмами для керівників, а також медичну та бізнес-освіту. Такий склад викладачів буде здатний підготувати менеджерів як з питань класичної теорії управління, так і з менеджменту, маркетингу, економіки, права, інфрормаційних технологій; менеджерів, які у своїй діяльності використовують науково обґрунтовані методи управління, а не тільки інтуїцію та практичний досвід.

Керівник закладу охорони здоров'я повинен направлятись на навчання, коли він вже має проект розвитку керованого ним закладу та у процесі вивчення навчальних дисциплін його розробляє і захищає у ході підсумкової атестації.

Функціонування системи підготовки менеджерів і використання цих кадрів на практиці дозволить адаптувати заклади охорони здоров'я до роботи на принципах державно-приватного партнерства.

\section{Висновки}

Узагальнюючи можна зробити висновок, що пріоритетними напрямками розвитку медичних закладів у нових економічних умовах $€$ фрормування їх господарського механізму на принципах державно-приватного партнерства та підготовка менеджерів для управління новим типом закладів.

Підготовка для системи охорони здоров'я сучасних менеджерів, які мають алгоритм мислення підприємців та орієнтуються у специфріці свого бізнесу і зможуть забезпечити запровадження принципів ДПП в охороні здоров'я, вимагає розробки спеціальних навчальних програм та організації спеціальних циклів для підготовки менеджерів.

Перспективи подальших досліджень будуть враховані при обґрунтуванні та розробці концептуальних напрямків формування сучасної моделі медичного закладу на принципах державно-приватного партнерства та механізмів управління нею.

\section{Список літератури}

1. Бондарєв Т. Реалізація державно-приватного партнерства у сфері охорони здоров'я України / Т. Бондарєв, Н. Поливка // Практика управління медичним закладом : щомісячний спеціалізований журнал. - 2011. - № 11. C. 58-66.

2. Гойда Н. Г. Державно-приватне партнерство в діяльності лікарні: світовий досвід та перспективи впровадження в Україні / Н. Г. Гойда, Н. В. Курділь // Східноєвроп. журн. громад. здоров'я. - 2012. - № 2/3. - С. 68-71.

3. Павлюк К. В. Охорона здоров'я: спробувати механізми державно-приватного партнерства / К. В. Павлюк // Незалежний аудитор. - 2013. - № 3. - С. 66-70.

4. Матаев Т. М. Определение и классификация фрорм государственно-частного партнерства / Т. М. Матаев // Российское предпринимательство. - 2014. - № 7 (253). - С. 51-58.

5. Державно-приватне партнерство: МОЗ України нарада з питань його впровадження у сфері охорони здоров'я [Електронний ресурс] / Актуальні питання міжнародної співпраці у сфері охорони здоров'я : матеріали Круглого столу з міжнародною участю, 17 грудня 2015 р., м. Київ. - Режим доступу : http://www.apteka.ua/article/338281

6. Про державно-приватне партнерство : Закон України від 1 липня 2010 р. № 2404-VI // Відомості Верховної Ради України від 08.10.2010. - 2010. - № 40. - С. 1436, стаття 524.

7. Про внесення змін до деяких законів України щодо усунення регуляторних бар'єрів для розвитку державноприватного партнерства та стимулювання інвестицій в Україні : Закон України від 24.11.2015 р. № 817-VIII // Відомості Верховної Ради України від 04.03.2016. - 2016. - № 10. - С. 5, стаття 97.

8. Друкер П. Ф. Энциклопедия менеджмента ; пер. с англ. / П. Ф. Друкер. - М. : Издательский дом «Вильяме». 2004. - $432 \mathrm{c}$.

9. Друкер П. Ф. Менеджмент. Вызовы XXI века ; пер. с англ. / П. Ф. Друкер. - М. : Издательский дом «Вильяме». 2012. - 162 c.

10. Портер Майкл Переосмысление системы здравоохранения / Майкл Портер, Элизабет Тайсберг. - К. : Изд. А. Капусты, 2007. - 599 с.

11. Геворкян А. Р. Векторы подготовки менеджеров для реализации муниципально-частного партнерства в здравоохранении / А. Р. Геворкян, Е. А. Берсенева // Успехи современной науки. - 2017. - № 7. - С. $171-176$.

\section{References}

1. Bondariev, T., \& Polivka, N. (2011). Realizatsiia derzhavno-pryvatnoho partnerstva u sferi okhorony zdorovia Ukrainy [Implementation of public-private partnership in the field of public health of Ukraine]. Praktyka upravlinnia medychnym zakladom: shchomisiachnyi spetsializovanyi zhurnal - Practice of Management of a Medical Institution: Monthly Specialized Journal, 11, 58-66 [in Ukrainian]. 
2. Hoida, N.H., \& Kurdyl, N.V. (2012). Derzhavno-pryvatne partnerstvo v diialnosti likarni: svitovyi dosvid ta perspektyvy vprovadzhennia v Ukraini [State-private partnership in the hospital activity: world experience and prospects of implementation in Ukraine]. Skhidnoievrop. Zhurn. hromad. Zdorovia - Eastern European Journal of Communities. Health, 2/3, 68-71 [in Ukrainian].

3. Pavliuk, K.V. (2013). Okhorona zdorovia: sprobuvaty mekhanizmy derzhavno-pryvatnoho partnerstva [Health: try the mechanisms of public-private partnership]. Nezalezhnyi auditor - Independent Auditor, 3, 66-70 [in Ukrainian].

4. Mataev, T.M. (2014). Opredelenie i klassifikatsiya form gosudarstvenno-chastnogo partnerstva [Definition and classification of forms of public-private partnership]. Rossiyskoe predprinimatelstvo - Russian Entrepreneurship, 7 (253), 51-58 [in Russian].

5. Public-private partnership: Ministry of Health of Ukraine meeting on its implementation in the sphere of health protection / Materials of the Roundtable with international participation "Topical issues of international cooperation in the field of healthcare" Kyiv, December 17, 2015 [Electronic resource]. - Mode of access: http://www.apteka.ua/article/338281

6. Law of Ukraine dated July 1, 2010 No. 2404-VI "On Public-Private Partnership". Bulletin of the Verkhovna Rada of Ukraine dated 08/10/2010. - 2010, No. 40, p. 1436, article 524

7. Law of Ukraine dated November 24, 2015, No. 817-VIII "On Amendments to Certain Laws of Ukraine Regarding the Elimination of Regulatory Barriers for the Development of Public-Private Partnerships and Stimulating Investments in Ukraine" / Bulletin of the Verkhovna Rada of Ukraine dated March 4, 2016 - 2016 p., № 10, p. 5, article 97

8. Druker, P.F. (2004). Entsyklopediya menedzhmenta. Per. S angl. [Encyclopedia of Management: translation from English]. Moscow: Izdatelskiy dom "Villyame" [in Russian].

9. Druker, P.V. Menedzhment. Vyzovy XXI veka [Management. Challenges of the XXI century]. Moscow: Izdatelskiy dom "Villyame" [in Russian].

10. Porter M.T., \& Taisberg, E.O. Pereosmyslenie sistemy zdravookhranenie [Reforming the health care system]. Kiev: Izd. A. Kapusty [in Russian].

11. Gevorgyan, A.R., \& Bersenev, E.A. (2017). Vektory podgotovki menedzherov dlya realizatsii munitsipalno-chastnogo partnerstva $v$ zdravookhranenii [Vectors of training managers for realization of municipal-private partnership in public health]. Uspekhi sovremennoy nauki - Successes of Modern Science, 7, 171-176 [in Russian].

\section{АКТУАЛЬНОСТЬ ПОДГОТОВКИ МЕНЕДЖЕРОВ ДЛЯ ВНЕДРЕНИЯ ГОСУДАРСТВЕННО-ЧАСТНОГО ПАРТНЕРСТВА В ЗДРАВООХРАНЕНИИ}

В.В. Кравченко

Национальная медицинская академия последипломного образования имени П.Л. Шупика, г. Киев, Украина

Цель: обосновать необходимость подготовки менеджеров для реализации государственно-частного партнерства в системе здравоохранения.

Материалы и методы. Для достижения поставленной цели в работе использованы общенаучные методы анализа, синтеза, обобщения, интерпретации научных данных, а также системный и структурнофрункциональный подходы.

Результаты. Обоснована целесообразность подготовки менеджеров, обладающих навыками эффрективного экономического управления, для учреждений здравоохранения коммунального и регионального уровней, переходящих на принципы государственно-частного партнерства.

Выводы. Управленческий аппарат действующих государственных и коммунальных учреждений здравоохранения не в состоянии использовать экономические рычаги и повысить социальную и экономическую эффрективность здравоохранения. Приоритетными направлениями развития медицинских учреждений в новых экономических условиях является формирование их хозяйственного механизма на принципах государственно-частного партнерства и подготовка менеджеров для руководства новым типом учреждений.

КЛЮЧЕВЫЕ СЛОВА: государственно-частное партнерство в здравоохранении; подготовка менеджеров для государственно-частного партнерства.

\section{ACTUALITY OF TRAINING OF MANAGERS FOR IMPLEMENTATION OF STATE-PRIVATE PARTNERSHIP IN HEALTH CARE \\ V.V. Kravchenko \\ P. Shupyk National Medical Academy of Postgraduate Education, Kyiv, Ukraine}

Purpose: to substantiate the need to train managers for the implementation of public-private partnership in the health care system.

Materials and Methods. To achieve this goal, general scientific methods of analysis, synthesis, generalization, interpretation of scientific data, as well as systemic and structural-functional approaches were used in investigation.

Results. The expediency of training managers possessing the skills of effective economic management for public health and regional healthcare facilities passing to the principles of public-private partnership is substantiated.

Conclusions. Managers of existing state and municipal medical institutions cannot use economic levers and improve the social and economic efficiency of health care. The formation of the economic mechanism of medical 
institutions on the principles of public-private partnership and the training a new type of managers are the priority directions of development of health care system in the new economic conditions.

KEY WORDS: public-private partnership in healthcare; training of managers for public-private partnership.

Рукопис надійшов до редакції 13.11.2017 p.

Відомості про автора:

Кравченко Василь Віталійович - заслужений лікар України, кандидат медичних наук, докторант кафредри управління охороною здоров'я НМАПО імені П.Л. Шупика. 